\title{
Estimation of Carbon Footprints from Diesel Generator Emissions
}

\author{
Abdul Qayoom Jakhrani \\ Faculty of Engineering, Universiti Malaysia Sarawak, \\ Kota Samarahan, Sarawak, Malaysia \\ e-mail: aqunimas@hotmail.com \\ Andrew Ragai Henry Rigit \\ Faculty of Engineering, Universiti Malaysia Sarawak, \\ Kota Samarahan, Sarawak, Malaysia \\ e-mail: arigit@feng.unimas.my
}

\author{
Al-Khalid Othman \\ Faculty of Engineering, Universiti Malaysia Sarawak, \\ Kota Samarahan, Sarawak, Malaysia \\ e-mail: okhalid@feng.unimas.my \\ Saleem Raza Samo \\ Faculty of Engineering, Quaid-e-Awam University of \\ Engineering, Science and Technology, Nawabshah, \\ Sindh, Pakistan \\ e-mail: sfaizsamo@yahoo.com
}

\author{
Shakeel Ahmed Kamboh \\ Faculty of Computer Science and Information Technology, Universiti Malaysia Sarawak, \\ Kota Samarahan, Sarawak, Malaysia \\ e-mail: shakeel.maths@yahoo.com
}

\begin{abstract}
The aim of this paper is to estimate the amount of carbon footprints emitted from diesel generators in terms of carbon dioxide. A constant load demand of $1.05 \mathrm{~kW}$ per hour $(6.3 \mathrm{~kW} / \mathrm{day})$ with six hours of operation of a diesel generator per day was selected for this analysis. The fuel consumption rate and carbon footprints in terms of carbon dioxide $\left(\mathrm{CO}_{2}\right)$ were determined. It was discovered that emission of carbon footprints increased by five folds as emission factor was increased from $1 \mathrm{~kg}$ to $5 \mathrm{kgCO}_{2} /$ liter. Similarly, the increment of a single $\mathrm{kW}$ rated power diesel generator at a constant emission factor increases $\mathbf{1 . 1}$ to $\mathbf{1 . 2}$ times carbon footprint emissions. It is revealed that the efficiency of diesel generator is inversely proportional to its rated power, fuel consumption rate and $\mathrm{CO}_{2}$ emissions. Therefore, the rated power of selected diesel generator should be close to the required load demand.
\end{abstract}

Keywords-carbon footprints; carbon dioxide emissions; diesel generator; fuel consumption rate

\section{INTRODUCTION}

The diesel generators are the most widely used as small electrical power generating units in off-grid locations in the world due to their low capital costs [1]. Sarawak Electricity Supply Corporation (SESCO) producing $68 \mathrm{MW}$ power from small diesel generating units for supply of electricity in rural communities living in remote locations from national grid. However, diesel engines release many hazardous air contaminants and greenhouse gases (GHG) including particulate matter (diesel soot and aerosols), carbon monoxide, carbon dioxide and oxides of nitrogen. Particulate matters are largely elemental and organic carbon soot, coated by gaseous organic substances such as formaldehyde and polycyclic aromatic hydrocarbons (PAHs) which are highly toxic [2]. In 2001, the mortality due to diesel soot exposure was at least 14400 people out of 82 million people living in Germany [3]. The total amount of greenhouse gases (GHGs) emitted by any system to support human activities directly and indirectly is termed as carbon footprint [4]. It is difficult to get all required data for every particular greenhouse gas emissions due to technical and monitoring problems. Therefore, for simplicity, it is often expressed in terms of the amount of carbon dioxide $\left(\mathrm{CO}_{2}\right)$ emitted [5]. The best way is to calculate the carbon dioxide emissions is based on the amount of fuel consumption by diesel generator [6]. Carbon content of fuels slightly varies, but typically the average carbon content values to estimate $\mathrm{CO}_{2}$ emissions could be adapted [7]. The consumption of one liter diesel emits around $2.7 \mathrm{~kg}$ of $\mathrm{CO}_{2}$ [8]. However, the number of $\mathrm{kg}$ of $\mathrm{CO}_{2}$ produced per liter of fuel consumed by the diesel generator depends upon the characteristics of the diesel generator and of the characteristics of the fuel, and it is usually falls in the range of 2.4-2.8 kg/1 [6]. Carbon foot prints can also be expressed in $\mathrm{kg}$ carbon rather than $\mathrm{kg}$ carbon dioxide [9]. It can be converted from $\mathrm{kg}$ carbon to $\mathrm{kg}$ carbon dioxide by multiplying with a factor 0.27 (i.e. 1000 $\mathrm{kg} \mathrm{CO}_{2}$ equals $270 \mathrm{~kg}$ carbon). The emission factor considered for a diesel generator was $1.27 \mathrm{~kg} \mathrm{CO}_{2} / \mathrm{kWh}$ [6], $3.15 \mathrm{kgCO}_{2} / 1$ [10] and $3.50 \mathrm{kgCO}_{2} / 1$ [11].

In remote areas, the diesel generators can be replaced by SAPV power producing units. The SAPV units are environmental friendly as did not produce any greenhouse gases which cause global warming [12-13]. The users can adapt the system capacity up to the desired level due to their modularity and expandability [14-17]. Additionally, the manufacturing cost of PV cell per watt has been dropped and its daylight-to-power conversion efficiency has also been increased [18-19]. It is estimated that by 2050, photovoltaic systems will provide around $11 \%$ of global electricity production and avoid 2.3 gigatones of $\mathrm{CO}_{2}$ emissions per year [20]. PV production has been increasing by an average

978-1-4577-2171-7/12/\$26.00 @2011 IEEE 